\title{
PENERAPAN ALAT BANTU PEMBELAJARAN UNTUK MENINGKATKAN HASIL BELAJAR SHOOTING BOLA BASKET
}

\author{
Tomi Hendra $S^{(1)}$ Agus Mukholid ${ }^{(2)}$ \\ (1)(2)(3) Universitas Sebelas Maret Surakarta
}

\begin{abstract}
This research aims at improving the learning outcome of the basketball shooting basis technique on the VIII-A grade students of SMP Negeri 14 Surakarta in the Academic Year of 2016/2017.

This research is conducted in two cycles in which each cycle consists of two meetings. The subjects of this research are $30 \mathrm{VIII}-\mathrm{A}$ grade students of SMP Negeri 14 Surakarta with 16 female students and 14 male students. The data collection technique uses observation, test, and documentation. The data validity uses data triangulation technique. The data are analyzed using qualitative and quantitative.

The research finding in the pre-cycle was that there were only 12 students who passed (40\%) and the other 18 students had not passed (60\%). In the cycle I, there were 19 students passed (63.3\%) and 11 students still had not passed $(36.67 \%)$ with the average score of affective (60\%), psychomotor $(76.67 \%)$, and cognitive (66.67\%). In the cycle II it is obtained that there were 25 passedstudents (83.33\%) and 5 students still had not passed (16.67\%). With the average score of affective (80\%), psychomotor (83.33\%), and cognitive (86.67\%). Based on the analysis result on the cycle I \& II, it shows an increase in learning outcome of basketball shooting.
\end{abstract}

Keywords: Learning outcome of basketball shooting, application of learning aid 


\section{PENDAHULUAN}

Pendidikan jasmani pada dasarnya merupakan sebuah kegiatan pendidikan yang mana tingkat belajar siswa serta minat dalam mengikuti pelajaran. Tujuan yang ingin dicapai melalui pendidikan jasmani tidak hanya pada aspek jasmani saja tetapi juga aspek kognitif, afektif, dan psikomotor. Disamping itu juga pendidikan jasmani merupakan pendidikan yang utama untuk menunjang prestasi siswa dan mencakup aspek mental, emosional, sosial, dan spiritual. Pendidikan jasmani diajarkan dari tingkat Sekolah Dasar (SD), Sekolah Menengah Pertama (SMP), Sekolah Menengah Atas (SMA), Sekolah Menengah Kejuruan (SMK), bahkan di Perguruan Tinggi.

Materi pendidikan jasmani dibedakan menjadi dua kelompok yaitu materi pokok dan materi pilihan. Materi pokok merupakan mata pelajaran yang wajib diajarkan berdasarkan kurikulum yang berlaku. Sedangkan materi pilihan merupakan kegiatan olahraga di luar jam pelajaran sekolah berupa kegiatan ekstrakulikuler olahraga. Bola Basket merupakan salah satu cabang olahraga permainan yang termasuk dalam materi pokok pendidikan jasmani. Sebagai olahraga pendidikan, teknik dasar dalam permainan bola basket diajarkan melalui proses pembelajaran pendidikan jasmani. Proses pembelajarannya lebih menekan pada proses pembelajarannya. Karena banyak siswa yang mengalami kesulitan dalam mengikuti proses pembelajaran bola basket.

Langkah awal dalam proses pembelajaran permainan bola basket yaitu memperkenalkan macammacam teknik dasar bola basket agar siswa memahami dan menguasainya. Teknik-teknik dasar dalam permainan bola basket diajarkan melalui proses pembelajaran pendidikan jasmani, mulai dari dribble, passing, pivot, shooting, maupun rebound. Dengan menguasai macam-macam teknik dasar bola basket, diharapkan siswa akan memiliki ketrampilan bermain bola basket. 
Berdasarkan hasil observasi mengindikasikan bahwa pembelajaran shooting bola basket khususnya siswa di kelas VIII A SMP Negeri 14 Surakarta Tahun Pelajaran 2016/2017 telah berjalan sebagaimana mestinya namun masih belum maksimal. Rendahnya hasil pembelajaran shooting tersebut diakibatkan oleh beberapa faktor yaitu: terkadang siswa merasa bosan dan jenuh terhadap pembelajaran tersebut karena kesulitan dengan ukuran dan berat bola, dan guru kurang akan pemakaian media alat bantu pembelajarn. Kondisi tersebut akan berdampak pada pencapaian hasil belajar siswa yang kurang memuaskan.

Hasil belajar yang kurang memauaskan terbukti dari hasil wawancara kepada kolaborator bahwa untuk data penilaian KKM permainan bola basket adalah 75 . Dan data penilaian yang diperoleh dari kelas VIII A yang berjumlah 30 siswa yaitu sebesar $60 \%$ atau 18 siswa yang yang belum tuntas atau di bawah KKM.

Untuk menciptakan hasil belajar yag memuaskan dari permasalahan diatas perlu dilakukan pembelajaran dengan alat bantu pemelajaran yang lebih menarik dan membantu meningkatkan hasil belajar yang memuaskan.

Dalam rangka mencapai tujuan tersebut, pembelajaran yang dilakukan antara guru dan siswa hendaknya mengacu pada peningkatan aktivitas dan partisipasi siswa. Guru tidak hanya melakukan kegiatan penyampaian pengetahuan, ketrampilan dan sikap kepada siswa akan tetapi guru diharapkan mampu membawa siswa untuk aktif dalam berbagai bentuk pembelajaran. Dari permasalahan di atas, maka peneliti akan melakukan penelitian dengan judul "PENERAPAN ALAT BANTU PEMBELAJAAN UNTUK MENINGKATKAN HASIL BELAJAR SHOOTING BOLA BASKET PADA SISWA KELAS VIII A SMP NEGERI 14 SURAKARTA TAHUN PELAJARAN 2016/2017”

\section{METODE PENELITIAN}

Penelitian ini menggunakan metode Penelitian Tidakan kelas (PTK). Teknik pengumpulan data 
dalam Penelitian Tindakan Kelas ini terdiri dari Tes dan Observasi.

1. Tes dipergunakan untuk mendapatkan data tentang hasil belajar shooting bola basket yang dilakukan siswa.

2. Observasi dipergunakan sebagai teknik untuk mengumpulkan data tentang aktivitas siswa dan guru selama kegiatan belajar mengajar saat penggunaan alat bntu bola.

\section{PEMBAHASAN}

Pelaksanaan penelitian tindakan kelas ini bertujuan untuk meningkatkan hasil belajar shooting bola basket. Penelitian ini dilaksanakan di kelas VIII-A SMPN 14 Surakarta melalui Penggunaan Alat Bantu Pembelajaran. Data awal pembelajaran shooting bola basket yang semula membosankan dan banyak keluhan dari siswa serta terbatasnya alat bantu pembelajaran dalam proses pendidikan jasmani yang mengakibatkan kurang mendapat tanggapan yang positif dari para siswa. Dengan menggunakan alat bantu pembelajaran yang mendukung shooting bola basket, pembelajaran menjadi tidak monoton, dan membangkitkan minat serta semangat siswa untuk mencoba dalam pembelajaran shooting bola basket.

Siklus I dilaksanakan 2 kali pertemuan yaitu pada senin tanggal 6 Februari dan 13 Februari 2017 di lapangan SMPN 14 Surakarta. Pelaksanaan tindakan I merupakan tindak lanjut dari hasil pratindakan yang menunjukan bahwa kelas VIIIA SMPN 14 Surakarta memiliki masalah dalam pembelajaran shooting bola basket.

Pelaksanaan tindakan I, siswa melakukan pembelajaran shooting bola basket dengan penggunaan alat bantu pembelajaran, yaitu pembelajaran shooting bola basket yang diterapkan dengan kegiatan intinya adalah menguasai teknik shooting dangan menggunakan alat bantu pembelajaran dengan tidak meninggalkan shooting bola basket itu sendiri. Dari hasil pengamatan yang dilakukan oleh peneliti dan kolaborator terhadap proses pembelajaran shooting bola basket menggunakan alat bantu 
pembelajaran pada siklus I masih terdapat beberapa kekurangan atau kelemahan yang berasal dari guru sebagai peneliti dan siswa.

Kelemahan dari segi guru yaitu guru masih mendominasi dalam memberikan bimbingan atau pengajaran, sulit memanajemen waktu dan guru juga sulit membuat siswa fokus dalam pemberian umpan dari guru untuk membuat siswa aktif dalam pembelajaran dan belum adanya penguatan untuk meningkatkan motivasi belajar siswa. Kelemahan dari segi siswa antara lain siswa masih sulit untuk melakukan gerakan menggunakan alat bantu pembelajaran, siswa lebih sering mengabaikan unsur shooting bola basket yang diterapkan dalam alat bantu pembelajaran, siswa juga masih kesulitan dalam melakukan shooting bola basket dengan benar. Nilai yang diperoleh siswa dari hasil pengamatan pembelajaran shooting bola basket pada tindakan siklus I masih harus ditingkatkan karena belum mencapai indikator keberhasilan yang telah ditetapkan.

Solusi yang disepakati peneliti dan kolaborator dalam pelaksanaan siklus II yaitu dengan adanya penambahan frekuensi gerakan dengan menggunakan alat bantu pembelajaran menambah keahlian siswa dalam shooting bola basket dan dengan pemberian reward berupa pujian, seperti : "bagus sekali" dan pemberian kesempatan melakukan lebih banyak semakin memacu siswa untuk lebih berusaha melakukan gerakan shooting bola basket dengan benar.

Guru juga harus berusaha memberikan materi secara menyeluruh kepada seluruh siswa dengan tidak terfokus memberikan materi dari depan saja, tetapi dari semua sudut yang memudahkan semua siswa untuk lebih memahami materi yang disampaikan. Kemudian pada siklus II ini guru juga harus meminimalisir kesalahan-kesalahan yang dilakukan siswa dalam melakukan shooting bola basket. Selain itu siswa juga dituntut harus lebih aktif agar siswa dapat mengetahui shooting bola basket secara menyeluruh.

Siklus I dalam penelititan ini masih belum mampu mencapai indikator keberhasilan yang telah 
ditetapkan sebelumnya. Oleh karena itu peneliti dan kolaborator mengadakan tindakan perbaikan dari siklus I, yaitu dengan merencanakan dan melaksanakan proses pembelajaran siklus II. Berdasarkan hasil observasi, analisis dan refleksi pada siklus I, peneliti bersama kolaborator merencanakan tindakantindakan yang akan dilakukan pada siklus II untuk mengatasi kelemahan proses pembelajaran shooting bola basket melalui penggunaan alat bantu pembelajaran yang telah dilaksanakan pada siklus I.

$$
\text { Perbaikan pada tindakan I, }
$$
pelaksanaan tindakan II menunjukan peningkatan. Dari pelaksanaan siklus II dapat dilihat peningkatan afektivitas, motifasi belajar dan kemampuan melakukan shooting bola basket. Sebelum pelaksanaan tindakan, siswa yang berhasil mencapai batas ketuntasan nilai pada angka 75 untuk shooting bola basket sebanyak 12 siswa atau sekitar $40 \%$. Selanjutnya mengalami peningkatan pada siklus I sebanyak 19 siswa dinyatakan mencapai nilai tuntas atau sekitar 63,33\%. Titik puncak peningkatan hasil belajar shooting bola basket pada penelitian ini adalah pada siklus II. Pada akhir siklus II siswa telah mencapai indikator keberhasilan yang telah ditetapkan. Sebanyak 25 siswa atau sekitar $83,33 \%$ siswa dinyatakan telah mencapai target ketuntasan. Dengan demikian, penelitian tindakan kelas siswa kelas VIII-A SMPN 14 Surakarta dalam upaya peningkatan hasil belajar shooting bola basket dengan menerapkan alat bantu pembelajaran ini telah mencapai keberhasilan pada pelaksanaan siklus II. Dengan tercapainya keberhasilan, maka penelitian ini dapat dikatakan berhasil dan dapat dihentikan.

Lebih jelasnya secara rinci peningkatan persentase kualitas hasil belajar shooting bola basket menggunakan alat bantu pembelajaran pada siswa kelas VIIIA SMPN 14 Surakarta dapat dilihat pada table berikut ini :

Tabel 3.8. Deskripsi Hasil Belajar Siswa pada Prasiklus, Siklus I, dan Siklus II 


\begin{tabular}{|c|c|c|c|c|}
\hline \multirow[b]{2}{*}{ Aspek } & \multicolumn{3}{|c|}{ Persentase Pencapaian } & \multirow{2}{*}{$\begin{array}{l}\text { Cara } \\
\text { Mengukur }\end{array}$} \\
\hline & Prasiklus & Siklus I & $\begin{array}{l}\text { Siklus } \\
\text { II }\end{array}$ & \\
\hline $\begin{array}{l}\text { Hasil } \\
\text { Belajar } \\
\text { Shooting } \\
\text { bola } \\
\text { basket }\end{array}$ & $40 \%$ & $63,33 \%$ & $83,33 \%$ & $\begin{array}{l}\text { Diukur Melalui } \\
\text { Ketuntasan Hasil } \\
\text { Belajar Shooting } \\
\text { bola basket (Afektif, } \\
\text { Kognitif Dan } \\
\text { Psikomotor) }\end{array}$ \\
\hline
\end{tabular}

Berdasarkan tabel diatas

disamping mempengaruhi

peningkatan kemampuan shooting bola basket pada siswa, penggunaan alat bantu pembelajaran dalam pembelajaran shooting bola basket juga berpengaruh terhadap afektif dan semangat siswa saat proses pembelajaran serta dibarengi dengan pemahaman siswa terhadap shooting bola basket. Cara ini dikatakan lebih efektif dalam hal penyampaian materi kepada siswa, karena dengan penggunaan alat bantu pembelajaran ini siswa diberi kebebasan untuk mengekspresikan kemampuanya. Melalui penggunaan alat bantu pembelajaran pada kelas VIII-A SMPN 14 Surakarta, mampu menigkatkan hasil belajar shooting bola basket. Sebab pembelajaran ini menitik beratkan pada proses pembelajaran yang menyenangkan dan hasil belajar yang memuaskan.
Melalui peningkatan yang terjadi sejak kondisi awal hingga diberikanya tindakan siklus I dan siklus II dapat disimpulkan bahwa penggunaan alat bantu pembelajaran dapat meningkatkan hasil belajar shooting bola basket pada siswa kelas VIII-A SMPN 14 Surakarta tahun ajaran 2016/2017.

Penelitian tindakan kelas pada siswa kelas VIII-A SMPN 14 Surakarta tahun ajaran 2016/ 2017 telah dilaksanakan dalam dua siklus dengan setiap siklus terdiri dari 2 pertemuan. Setiap siklus terdiri atas empat tahapan, yaitu:

Perencanaan, (2) Pelaksanaan atau Tindakan, (3) Observasi atau Pengamatan , (4) Refleksi atau Evaluasi. Berdasarkan tindakan penelitian yang telah dilakukan dan hasil observasi yang telah diungkapkan pada BAB IV, diperoleh hasil sebagai berikut:

Hasil penelitian menunjukkan peningkatan dari pra siklus ke siklus I dan dari siklus I ke siklus II. Dari 30 siswa yang mencapai ketuntasan hasil belajar shooting bola basket pada pra siklus sebesar $40 \%$ (12 siswa). Pada siklus I sebesar 63,33\% 
(19 siswa) dan pada siklus II sebesar 83,33\% (25 siswa) sedangkan yang belum tuntas diakhir siklus II $16,67 \%$ sebesar (5 siswa). Hasil belajar shooting bola basket meningkat pada siklus I walaupun belum optimal. Pelaksanaan siklus II yang merupakan perbaikan dari pelaksanaan pembelajaran pada siklus I menunjukkan adanya peningkatan hasil belajar shooting bola basket hingga mencapai target yang ditetapkan peneliti.

\section{SIMPULAN DAN DARAN}

\section{Simpulan}

Simpulan penelitian ini
adalah melalui penggunaan alat
bantu
meningkatkan hasil belajar shooting bola basket pada siswa kelas VIII-A SMP N 14 Surakarta tahun ajaran 2016/ 2017.

\section{Saran}

Sesuai dengan simpulan dan implikasi hasil penelitian tindakan kelas yang telah diungkapkan diatas, serta dalam rangka upaya bagi guru dalam meningkatkan penguasaan belajar, khususnya bidang studi penjasorkes, maka dapat disampaikan saran-saran:

Bagi Guru

a. Guru hendaknya terus berusaha untuk meningkatkan kemampuannya dalam mengembangkan materi, menyampaikan materi, serta dalam mengelola kelas, sehingga kualitas pembelajaran yang dilakukannya dapat terus meningkat seiring dengan peningkatan kemampuan yang dimilikinya. Selain itu, guru hendaknya mau membuka diri untuk menerima berbagai bentuk masukan, saran, dan kritikan agar dapat lebih memperbaiki kualitas mengajarnya.

b. penggunaan alat bantu pembelajaran sebagai alternatif inovasi pembelajaran penjasorkes Bagi Siswa

Siswa harus mampu menumbuhkan nilai-nilai yang terkandung dalam pelajaran dan menerapkannya, seperti disiplin, berani, tanggung jawab serta nilai lain dalam pembelajaran penjasorkes. 


\section{DAFTAR PUSTAKA}

Agus Kristiyanto. (2010).Penelitian Tindakan Kelas (PTK) Dalam Pendidikan Jasmani \& Kepelatihan Olahraga. Surakarta : UNS Press

Agus Margono. (2010). Permainan Bola Basket. Surakarta: UNS Press.

Aunurrahman. (2012). Belajar dan Pembelajaran. Bandung: Alfabeta.

Danny Kosasih. (2008) Fundamental Basketball First Step To Win. Semarang:

Karangturi Media

Dedy Sumiyarsono. (2002). Keterampilan Bola Basket. Yogyakarta: Fakultas Ilmu Keolahragaan. Universitas Negeri Yogyakarta.

Dimyati dan Mudjiono. (2010). Belajar dan Pembelajaran. Jakarta: Departemen Pendidikan dan Kebudayaan

FKIP UNS. (2016). Pedoman Penulisan Skripsi FKIP UNS. Surakarta.

Hamdani. (2011). Strategi Belajar Mengajar. Bandung: CV Pustaka Setia

Imam Sodikun. (1992). Olahrag Pilihan Bola Basket. Jakarta: Depdikbud Dirjendikti Proyek Pembinaan Tenaga Kependidikan.

Lutan, Rusli dan Adang Suherman. (2000). Perencanaan Pembelajaran Penjaskes. Jakarta: Depdikbud. Direktoral Jendral Pendidikan Dasar dan Menengah. Bagian Proyek Penataran Guru SLTP Setara D-III.

M. Sobry Sutikno. (2013). Belajar dan Pembelajaran "Upaya kreatif dalam mewujudkan pembelajaran yang berhasil”. Lombok: Holistica

Nuril Ahmadi. (2007). Permainan Bola Basket. Surakarta: Era Intermedia.

Samsudin. (2008). Penbelajaran Pendidikan Jasmani Olahraga dan Kesehatan (SD/MI). Jakarta: Litera

Soekidjo. (2003). Alat Bantu Pembelajaran. Jakarta: Rineka Cipta

Suyono dan Hariyanto. (2014). Belajar dan Pembelajaran. Bandung: PT. Remaja Rosdakarya

Toho Cholik M. dan Rusli Lutan. (2001). Pendidikan Jasmani dan Kesehatan. Bandung: CV. Maulana 